\title{
Epistemologi Pembaharuan Usul Fikih Hasan Turabi
}

\section{Jamaluddin}

\author{
Dosen Fakultas Agama Islam Universitas Islam \\ Sumatera Utara Medan \\ Email : najwandua@gmail.com
}

\begin{abstract}
The article is the research result of the reform of Ushul Al Fiqh proposed by Hasan Turabi. The method applied is descriptive qualitative, exposing the entire ideas of Hasan Turbi pertaining to the reform of Ushul Fiqh and proceeded by the approach of content analysis. The next step is to make comparison with ideas of other Ushul Fiqh scholars. The reform of Ushul Fiqh according to Hasan Turbi is to implement qiyas al-wasi (wide qiyas) and istishab al-wasi (wide qiyas). The method applied by Hasan Turbi has already been used by former Ushul Fiqh scholars. Hasan Turbi only adds the words al-wasi. The essence of qiyas alwasi and istishab al-wasi by Hasan Turabi is traditional issues already been done for a long time in a certain community or actual issues.
\end{abstract}

Key Words : Tajdid, al-Qiyās wāsi', Istishāb al-Wāsi ‘

Abstrak

Artikel ini merupakan hasil penelitian dari reformasi Ushul Al Fiqh yang diajukan oleh Hasan Turabi. Metode yang digunakan adalah deskriptif kualitatif, mengungkap keseluruhan gagasan Hasan Turbi yang berkaitan dengan reformasi Ushul Fiqh dan dilanjutkan dengan pendekatan analisis isi. Langkah selanjutnya adalah membandingkannya dengan gagasan para ilmuwan Ushul Fiqh lainnya. Reformasi Ushul Fiqh menurut Hasan Turbi adalah menerapkan qiyas al-wasi (qiyas lebar) dan istishab al-wasi (qiyas lebar). Metode yang diterapkan oleh Hasan Turbi telah digunakan oleh mantan sarjana Ushul Fiqh. Hasan Turbi hanya menambahkan kata al-wasi. Inti dari qiyas alwasi dan istishab al-wasi oleh Hasan Turabi adalah isu-isu 
tradisional yang sudah lama dilakukan dalam masyarakat tertentu atau isu aktual.

Kata Kunci: Tajdid, al-Qiyās wāsi ', Istishāb al-Wāsi'

\section{A. Pendahuluan \\ 1. Latar Belakang}

Islam sebagai agama yang sempurna, yang ajarannya mencakup segala aspek kehidupan manusia. Kesempurnaan Islam itu dapat dilihat dari tujuan syaria'at itu sendiri, yaitu untuk mendapatkan kebahagiaan dan kemaslahatan umat manusia baik di dunia mapun di akhirat.

Untuk mendapatkan tujuan hidup yang hakiki, Allah swt telah menurunkan Alquran, yang dibawa oleh Nabi Muhammad saw. Ajaran yang terkandung dalam Alquran, mencakup akidah, syari'ah, dan akhlak. Didalam syari'ah tersebut ada satu perangkat undang-undang yang mengatur cara hidup manusia dan tata cara ibadah ritual kepada Tuhannya, seperti salat, zakat, munakahat, jinayat dan lainlain, yang perangkat tersebut dinamakan dengan fikih. Fikih ialah: "ialah suatu ilmu yang berhubungan dengan hukum syara' yang diamalkan yang diambil dari dalil-dalil yang tafsīliyah. ${ }^{1}$

Usaha ataupun cara untuk menghasilkan materi fikih dari dalil-dalil yang tafsiliyah tersebut adalah usul fikih.Usul fikih ialah: Pengetahuan kaedah-kaedah yang menyampaikannya kepada istinbāt hukum syara' yang furū ' melalui dalil-dalil yang terperinci. ${ }^{2}$

Usul fikih merupakan ilmu pokok yang harus dimiliki bagi seorang yang ingin melakukan istinbāt dari Alquran maupun hadis Rasulullah saw. Usul fikih merupakan instrumen yang sangat penting, tanpa adanya usul fikih, seseorang tidak akan bisa beristidlāl dengan benar, karena didalam usul fikih kita akan mengetahui tatacara maupun metode untuk menggali hukum-hukum yang langsung dari nasnya.

${ }^{1}$ Muhammad Abū Zahrah, Usūl al-Fiqh (Kairo:Dār al-Fikr al'Arabī,t.t), h.5

${ }^{2}$ Muhammad ibn 'Alī ibn Muhammad asy-Syawkān̄̄, Irsyād alFuhūl (Beirut:Dār al-Kutub al-'Arabiyah,t.t.), h.5 
Usul fikih telah dirumuskan secara komprihensif menjadi suatu ilmu yang berdiri sendiri sejak abad ke II H. ${ }^{3}$ Tujuan yang hendak dicapai dari ilmu usul fikih ialah untuk menerapkan kaedah-kaedah terhadap dalil-dalil syara' yang terperinci agar sampai kepada hukum-hukum syara' yang bersifat amali yang ditunjuk oleh dalil-dalil tersebut. Apabila kita sudah mengetahui metode usul fikih yang telah dirumuskan oleh para ahli-ahli usul fikih terdahulu, maka bila terjadi suatu peristiwa hukum yang membutuhkan penyelesaiannya, sedangkan masalah tersebut tidak ditemui didalam kitab-kitab fikih klasik, maka kita akan dapat mencari hukum masalah hukum tersebut dengan cara menerapkan ataupun memakai kaedah-kaedah hasil rumusan para ahli usul fikih yang telah tersebar didalam kita-kitab usul fikih terdahulu, seperti ar-Risālah yang disusun oleh Imam as-Syāfi'‘̄ (w.204 H), Kitāb al-Mu'tamad, yang disusun oleh Abū al-Husain Muhammad ibn 'Alī al-Bisri (w.463 H), dari aliran mutakallimin. Kitāb al-Usūl yang disusun oleh Imam Abū al-Hasan Ubaidillah ibn Hasan al-Kharkhī (w.340 H/952 M), Kitab Usūl yang disusun oleh Abū Bakr al-Jassās dari aliran atau Hanafiyah.

Para mujtahid sesudah Imam Syāfi'‘̄ dalam beristidlal maupun melakukan istinbāt untuk menghasilkan suatu produk fikih, mereka menggunakan kaedah-kaedah yang telah disusun maupun telah dirumuskan oleh ulama-ulama mujtahid sebelumnya, sehingga ada istilah dengan mujtahid mazhab.

Praktek ijtihad yang telah berlaku sudah menelan usia lebih kurang 1000 tahun, sedangkan kaedah-kaedah yang digunakan masih tetap baku dan tidak ada perobahan. Disisi lain, zaman telah berobah, peristiwa-peristiwa hukum terus bermunculan dan jauh berbeda pada masa kaedah-kedah usul fikih itu disusun. Apakah kaedah-kaedah tersebut masih relevan untuk dipakai pada zaman modern, atau diperlukan perubahan-perubahan yang disesuaikan dengan kondisi saat sekarang ini. 


\section{Rumusan Masalah}

Dalam tulisan ini penulis akan mengemukakan pendapat maupun pemikiran Hasan Al-Turabi, tentang perlunya mengadakan pembaharuan Usul Fikih.

\section{B. Kerangka Teori \\ 1. Pengertian Pembaharuan}

Secara etimologi pembaharuan berasal dari kata :" Jaddada dan dikatakan ajadda asy-syai artinya menjadikan sesuatu itu baru. ${ }^{4}$

Secara terminologi, tajdīd berarti pembaharuan dalam kehidupan keagamaan, baik berbentuk pemikiran ataupun gerakan, sebagai reaksi atau tanggapan terhadap tantangantantangan internal maupun eksternal yang menyangkut keyakinan dan urusan sosial umat. ${ }^{5}$ Tajdid diartikan juga sebagai upaya dan aktivitas untuk mengubah kehidupan umat Islam dari keadaan yang sedang berlangsung kepada keadaan yang hendak diwujudkan dalam upaya untuk kesejahteraan (kemaslahatan hidup) umat manusia.

Menurut Karen Amstrong tajdid ialah gerakan pembaharuan yang berusaha memulihkan Islam ke kemurniannya dengan kembali ke Alquran dan sunnah dengan menolak legeslasi dan praktik yang muncul kemudian. ${ }^{6}$ Pembaharuan menurut Karen Amstrong adalah pemurnian artinya kondisi umat sudah melenceng dan lari dari nilai-nilai yang sudah digariskan di dalam Alquran dan sunnah. Dengan demikian perlu adanya pemurnian ajaran Islam agar bersih dan lebih steril dari unsur-unsur yang tidak berasal dari Islam.

Khusus mengenai pembaharuan usul fikih, Dr Sya bān Muhammad 'Ismā'îl megemukakan bahwa yang dimaksud dengan pembaharuan Usul Fikih ialah:"Merekontruksi

${ }^{4}$ Luois Mahluf, al-Munjid F̄̄ al-Lugah wa al-A 'lām (Beirut: Dār al-Masyriq,1986), h.81

6 Karen Amstrong, Berperang demi Tuhan Fundamentalisme Dalam Islam, Kristen, dan Yahudi (Bandung: PT Mizan Pustaka, 2004), h. 570 
kembali bangunan usul fikih, agar menjadi baru, dengan bentuk yang sesuai dengan kehendak zaman.?

Dalam masalah tajdìd ini, ada sebuah hadis riwayat dari Abū Dāwud, yaitu:

Artinya:" Dari Abi Hurairah, ia mengatakan tentang apa yang pernah aku ketahui dari Rasulullah saw ia bersabda:" Sesungguhnya Allah akan membangkitkan untuk umat ini pada setiap awal seratus tahun seseorang yang melakukan pembaharuan agamanya. ${ }^{8}$

Adapun tokoh-tokoh yang mempelopori gerakan pembaruan yang disebut dengan mujaddid antara lain : Muhammad Bin Abdul Wahhab, Syah Waliyulloh, Sultan Mahmud II, Muhammad Ali Pasha, At-Tahtawi, Jamaluddin al-Afghani, Muhammad Abduh, Muhammad Rasyid Ridha, Sayyid Ahmad Khan, dan Muhammad Iqbal.

Az-Zabīdī menjelaskan bahwa mujaddid di abad ke I 'Umar ibn 'Abd al-'Azīz, abad ke II Imam asy-Syāfi'‘̄, abad ke III Al-Asy'arī atau Ibn Suraij, abad ke IV Al-Asfāin̄̄, AsSa'lūkī atau Al-Bāqilānī dan abad ke V ialah Al-Gazālī.'

\section{Biografi Hasan Al-Turabi}

Dr Hasan Al-Turabi lahir di Kassala, Sudan Timur, pada tahun 1932, dari keluarga yang memiliki tradisi panjang dalam pengajaran Islam dan sufisme. Dia tamat dari Fakultas Hukum Universitas Khartoum pada 1955, menyelesaikan pendidikan S-2 dalam bidang Hukum di London. Pada tahun 1957, ia memperoleh gelar Ph.D, dalam bidang Hukum Tata Negara dari Universitas Sorbonne, Paris pada tahun 1964. Selama ia menetap di Prancis, antara tahun 1959 hingga 1964, dia pernah melakukan kunjungan ke Amerika.

Dr Hasan Al-Turabi menjadi Dekan Fakultas hukum universitas Khartoum, jabatan yang kemudian ditinggalkannya ketika dia menjadi anggota parlemen dan Sekretaris Jenderal Islamic Charter pada Desember 1964.

7 Sya'bān Muhammad 'Ismā'īl, at-Tajdīd Fī Usūl al-Fiqh (Mekah:Maktabah al-Makkiyah,2000), h.41

${ }^{8}$ Abī Dāwud Sulaimān ibn al-Asy'aś as-Sijistāny al-Azdī, Sunan Abī Dāwud (Indonesia:Maktabah Dahlān,t.t.), Jil IV, h.109

${ }^{9}$ Muhammad ibn Muhammad al-Husainī az-Zabīdī, Ittihāf asSādah al-Muttaqīn ( Beirut:Dār al-Kutub al- 'Ilmiyah, 1989 ), Jil I, h.35 
Pada tahun 1969, setelah berlangsungnya upaya kudeta oleh kaum kiri, untuk pertama kalinya dia mendekam di penjara Sudan hingga tahun 1977, tahun ketika ia memilih Perjanjian Rekonsiliasi Nasional dengan Nameiri. Dia menjadi jaksa Agung dari tahun 1979 hingga 1982, dan menjadi kepala penasehat masalah-masalah hukum dan luar negeri hingga Maret 1985. Dia dan pemuka-pemuka gerakan Islam lainnya kemudian dijebloskan ke penjara, dan hanya dibebaskan ketika rejim Nomeiri jatuh.

Pada tahun 1988, Front Nasional Islam (NIF) yang dipimpin oleh Hasan Turabi berkoalisi dengan pemerintahan Shadiq Al-Mahdi dan mengantarkannya menjadi jaksa agung, lalu deputi perdana menteri dan menteri luar negeri. Dia pernah menjabat Sekretaris Jenderal Kongres Islam Khartoum yang beranggotakan partai-partai, kelompokkelompok, dan tokoh-tokoh gerakan nasionalis Islam yang berasal dari 55 negara Islam dan Barat. Sejak pemilu tahun 1966, dia menjabat sebagai ketua parlemen, kedudukan kedua yang paling berkuasa di negerinya, sesudah presiden yang dijabat oleh jenderal Umar Al-Basyir, juniornya di partai NIF

Hasan Al-Turabi selain seorang yang sibuk dan aktif di berbagai organisasi, baik di dalam pemerintahan negara Sudan ataupun dalam grup-grup dan organisasi sosial lainnya yang bersifat nasional maupun internasional, dia aktif juga menulis berbagai karya ilmiah, yang diantaranya adalah satu artikel tentang "The Islamic State" (Negara Islam), dan sebuah buku dengan yang berjudul Tajdìd Usul al-Fiqh alIslāmì.

\section{Pembaharuan Usul Fikih Hasan Turabi}

Metode istinbat hukum yang tersebut di dalam bukubuku Usul Fikih baik klasik ataupun yang modern yang beredar di kalangan umat Islam secara umum hampir seluruhnya menunjukkan kesamaan. Metode yang dibuat oleh ulama klasik seperti Imam Asy-Syafi'i disesuaikan dan dipengaruhi dengan kondisi pada masa ia hidup. Demikian

${ }^{10}$ Hasan Al-Turabi, Fiqih Demokratis, Terj Abdul Haris dan Zainul Am (Bandung:Arasy ,2003), h.12 
juga ulama-ulama yang lain $b \bar{\imath}$ 'ah (lingungan) sangat mempengaruhi alur dan pikirnya dalam membuat maupun mengkontruksi bangunan Usul Fikih.

Di sisi lain sekarang ini zaman sudah berobah sehingga menimbulkan pemikiran apakah metode-metode lama tersebut masih dapat diterapkan untuk menyahuti zaman. Hasan Turabi berpendapat bahwa pada saat ini perlu mengkaji kembali usul fikih dalam konteks hubungan dengan realitas kehidupan. Karena produk usul fikih klasik masih bersifat abstrak, wacana, dan hanya masih seputar teoritis, yang tidak mampu melahirkan fikih dan justru melahirkan perdebatan yang kunjung tidak selesai. Padahal, fikih dan usul fikih semestinya terus berkembang dalam menghadapi tantangan realitas kehidupan modern. ${ }^{11}$

Saat ini, urgensi pengembangan pemikiran metodologi usul fikih dalam konteks relevansinya dengan kebutuhan masyarakat Islam modern sangat mendesak. Ini disebabkan Islam sebagai agama yang dinamis, dituntut uantuk memecahkan berbagai persoalan modern secara lebih mendalam setelah sebelumnya mempfokuskan diri pada prinsip-prinsip agama dan banyak menghasilkan masalah furū 'iyah.

Ilmu-ilmu rasional modern telah mengalami perkembangan sangat pesat.Oleh karena itu, sudah selayaknya kaum muslim mengkaji kembali fikih Islam dengan persepsi baru, memanfaatkan segala ilmu sebagai sarana ibadah kepada Allah, dan membuat format baru yang menyatukan antara ilmu tekstual dan ilmu rasional yang selalu mengalami pembaruan dan kesempurnaan lewat eksperimentasi dan observasi. Dengan integrasi ilmu, kita akan dapat memperbaharui pemahaman agama kita dan memenuhi tuntutan kehidupan modern sepanjang masa.

\section{Kebutuhan terhadap Metodologi Usul Fikih}

Untuk menyelesaikan masalah-masasalah yang berkembang dimasyarakat modern saat ini, Hasan Turabi

${ }^{11}$ Nawir Yuslem, Gerakan Hasan Turabi Tentang Tajdīd Usūl AlFikih,dalam Analytica Islamica(Vol.3 No.1, Mei 2001), h.106 
menawarkan sebuah metodologi yang dapat diterima oleh semua orang, yaitu metodologi integratif. Metodologi yang ditawarkan oleh Hasan Turabi ini, menawarkan kembali kepada prinsip musyawarah dan ijmak yang menghimpun berbagai perbedaan pendapat dan kemudian diambil kesepakatan bersama (konsensus) agar ada sebuah pendapat saja yang dijadikan acuan. Pendapat yang telah memperoleh kesepakatan mayoritas muslim dan merupakan keinginan bersama dalam tataran aplikatifnya ini menjadi hukum yang wajib diikuti, meskipun mereka berbeda pendapat rentang kebenaran relatifnya.

Selanjutnya Hasan Turabi menjelaskan, bahwa pada saat sekarang ini kebutuhan metodologi Usul Fikih yang dapat dijadikan landasan untuk kebangkitan Islam sudah sangat mendesak. Disamping itu Usul Fikih yang tradisional yang selama ini kita jadikan acuan untuk beristinbat, sudah tidak relevan lagi untuk menyahuti kondisi zaman yang sudah modern. Lagi pula secara historis Usul Fikih klasik dengan seperangkat kaedah-kaedahnya dipengaruhi oleh watak problematika fiqih yang menjadi pembahasan fikih pada waktu itu. ${ }^{12}$

Metodololgi usul fikih memiliki keluasan dan standar yang beragam sesuai dengan jenis persoalan cabang yang ditinjau. Ada persoalan fikih yang sifatnya ubudiah dan ritual kepada Allah, seperti salat, puasa, dan haji. Hukum-hukum mengenai masalah ibadah ini telah diperinci secara detail dalam berbagai nas atau teks yang sangat banyak sehingga ruang lingkup ijtihad menjadi terbatas sekali dalam masalah ini, dan pemahaman para ahli fikih hanya sekedar menghimpun berbagai nas itu dan menghubungkannya dengan nas lain, hingga membentuk gambaran utuh tentang ibadah. Dengan demikian, persoalan usul fikih hanya berkisar pada soal penafsiran maupun interpretrasi nas, umpamanya mengkaji masalah 'ām dan khās, ta 'ärud, tarjīh, mafhūm mukhālafah, mafhūm muwāfaqah dan lain-lain.

Fikih tradisional juga terpaku pada masalah-masalah seperti ini. Para ahli fikih tidak banyak menyelesaikan

12 'Abd as-Salām al-Balājy, Tatawwur 'Ilm Usul al-Fiqh wa Tajaddudahu (T.t.p: Dār al-Wafā', 2007/1428) h.262 
persoalan-persoalan kehidupan publik, karena hanya duduk di majelis-majelis ilmu yang sudah disediakan. Oleh karena itu kehidupan publik jauh dari mereka. Pola fatwa mereka hanya seputar masalak furū', dan sedikit sekali ulama yang menulis kitab-kitab tentang metodologi teoritis. Karenanya, kebanyakan fiqih berorientasi kepada persoalan-persoalan yang berkaitan individual dan ibadah ritual, seperti, perkawinan, talak, beberapa tatakrama, dan sebahagian besar nasnya tidak banyak menimbulkan perbedaan pendapat.

Kehidupan umat Islam pada masa ini, telah banyak menyimpang jauh dari tujuan Islam, terutama dalam persoalan-persoalan kehidupan publik. Sedangkan fatwa yang selama ini diberikan hanya berkisar pada persoalan bagaimana melakukan transaksi jual beli, sementara persoalan-persoalan kebijakan umum ekonomi, seperti mengatur kehidupan masyarakat dalam bidang produksi, impor, ekspor, dan mengatasi mahalnya kehidupan atau rendahnya beban hidup, belum diperhatikan oleh pemegang otoritas persoalan, serta belum ditanyakan kepada para ahli fikih untuk dituangkan dalam bidang fikih yang seharusnya.

Begitu pula, persoalan-persoalan politik berikut aturanaturan praktisnya, seperti bagaimana musyawarah dilakukan dalam masyarakat, kristalisasi ijmak, dan bagaimana bentuk pemerintahan, ketaatan serta kepemimpinan umum secara global, belum banyak dipertanyakan.

Demikian juga nas-nas agama dalam bidang kehidupan publik ini lebih sedikit jumlahnya. Berbagai nas dalam masalah ini lebih merupakan tujuan ketimbang bentuk (ibadah). Misalnya saja tentang masalah kepemimpinan, kita tidak akan menemukan nas sebanyak nas tentang salat, demikian juga masalah ekonomi. Hasan Turabi mengemukakan, bahwa fikih yang memperhatikan persoalan tujuan kehidupan publik dan kemaslahatan tidak dikembangkan sedemikian rupa, disebabkan oleh kondisi dan situasi yang melingkupi pertumbuhan fikih dan perkembangan kehidupan Islam waktu itu. Karenanya tidak mengherankan kalau konsep-konsep usul fikih yang sesuai dengan bidang ini telah dilupakan dan tidak berkembang lagi. Ketika kehidupan Islam mulai lengkap dan praktek-praktek ekonomi dan politik masyarakat berpegang pada agama, 
kondisi seperti ini membutuhkan kaedah-kaedah usul fikih baru yang relevan.

Tajdid yang ditawarkan oleh Hasan Turabi tersebut, penekanannya adalah terhadap masalah-masalah yang berkaitan erat dengan kepentingan umum, khususnya aspekaspek sosial dalam masyarakat, karena permasalahan demikianlah yang memerlukan suatu konsep ijtihad yang lebih konprehensif (ijtihād wāsi'ah), sehingga dapat memenuhi kebutuhan kehidupan modern.

Dalam pelaksanaan tajdid usul fikih ini, ia menawarkan beberapa konsep yang menurutnya dapat menyelesaikan berbagai permasalahan kehidupan umat masa kini, yaitu:

1. Penggunaan al-Qiyās al-Wāsí(qiyas yang luas dan konprehensif)

Menurut Hasan Turabi, bahwa qiyas tradisional, yaitu yang diwariskan oleh ulama terdahulu, tidak lagi dapat memenuhi kebutuhan kehidupan manusia modern, karena jangkauannya sangat terbatas dan sifatnya kaku. Qiyas serupa itu, dalam pandangannya dapat dipergunakan untuk merumuskan hukum-hukum yang berkaitan dengan masalah perkawinan, moral dan masalah-masalah keagamaan lainnya. Sedangkan untuk tujuan-tujuan yang sifatnya lebih umum dan lebih luas lagi, maka qiyās alfitri (qiyas murni) atau qiyas yang lebih luas dan konprehensiflah yang lebih sesuai dan dibutuhkan, karena qiyas yang demikian tidak terikat dengan perasyaratanpersyaratan yang murni yang ditetapkan oleh para ahli logika Yunani, yang selanjutnya diadopsi oleh ulama Islam dalam merumuskan hukum-hukum Islam.

Konsep qiyas yang dimaksudkan oleh Hasan Turabi yang juga disebutnya dengan al-qiyās al-wāsi 'tersebut, operasionalnya adalah dengan cara mempelajari sejumlah ayat-ayat Alquran atau hadis-hadis Nabi saw, kemudian dari padanya dirumuskan beberapa tujuan yang spesifik atau kemaslahatan tertentu yang dituju oleh syara' dalam hukum, dan kemudian tujuan-tujuan dan kemaslahatn yang spesifik tersebut diaplikasikan kepada permasalahan dan kondisi baru dalam perumusan hukum-hukumnya. Qiyas yang seperti ini, menurut Hasan Turabi adalah serupa dengan apa yang dilakukan oleh Khalifah Umar ibn 
Khattab. Qiyas ini juga dinamai dengan fiqh masālih 'ammah wāsi'ah (fikih yang didasarkan kepada kemaslahatan umum). ${ }^{13}$

Konsep al-qiyās al-wāsi', menurut Turabi, diambil basisnya dari maslahah mursalah, selain dari nas itu sendiri. Qiyas jenis ini juga dinamai dengan al-qiyās alijmālì al-awsa' atau qiyās al-maslahah al-mursalah.

Langkah-langkah untuk melakukan qiyas ini ialah:

1) Dimulai dengan mengumpulkan sejumlah nas ayat-ayat Alquran atau hadis, yang selanjutnya dirumuskan dari padanya tujuan atau maslahah tertentu dari suatu yang dikandung oleh koleksi ayat atau hadis tersebut.

2) Menggunakan tujuan atau maslahah yang spesifik yang telah dirumuskan tersebut sebagai dasar dalam menetapkan hukum bagi kasus-kasus baru yang terjadi dalam situasi dan kondisi yang baru pula, tanpa harus melihat kepada bentuk dan kondisi kasus-kasus tersebut secara rinci. Hanya makna dan kemaslahatanlah yang dipertimbangkan, dan setelah itu hukum dari kasus-kasus terdahulu diaplikasikan kepada kasus yang baru, berdasarkan persamaan makna dan kemaslahatan yang dimiliki oleh keduanya. Akhirnya, dengan berpedoman kepada prosedur demikian, persoalan-persoalan baru yang dihadapi kehidupan modern ini dapat ditemukan solusinya. ${ }^{14}$

Hasan Turabi memberikan contoh mengenai konsepnya tentang qiyas diatas dengan mengutip sebuah hadis Nabi saw yang memuat kisah tentang seorang suami yang melakukan hubungan (jima') dengan isterinya di siang hari Ramadan, yang akibatnya puasanya menjadi batal dan dia dikenai hukuman. Akan tetapi, setelah dipelajari keadaannya, Nabi saw akhirnya membebaskan hukuman tersebut. Sabda Nabi saw:

Dari Abu Hurairah r.a. telah berkata ia : "Datang seorang laki-laki kepada Nabi saw lalu ia berkata: Telah celaka aku ya Rasulullah, lalu Nabi berkata :" Apa yang

${ }^{13}$ Muhammad bin 'Aly bin Muhammad asy-Syaukāny, Nail alAwtār (Mesir: Muṣtafā al-Bāb al-Halaby, t.t), Jil IV h.240 
membuat kamu celaka? Berkata laki-laki itu :" Aku telah mensetubuhi isteriku di siang Ramadan, lalu Nabi berkata:' Apakah engkau dapat memerdekakan seorang hamba? Berkata laki-laki itu:" Saya tidak sanggup ya Rasulullah, maka jika tidak sanggup, maka apakah engkau sanggup puasa dua bulan berturut-turut? Berkata laki-laki itu :"Saya tidak sanggup. Lalu berkata Nabi:" Apakah engkau sanggup memberi makan 60 orang miskin? Berkata laki-laki itu saya tidak sanggup lalu ia duduk, kemudian Nabi membawakan sekeranjang korma, lalu Nabi berkata:" Bersedekahlah dengan ini, apakah kepada orang yang lebih fakir dari kami? diantara ahli keluarga yang lebih membutuhkan adalah kami, lalu Nabi saw tertawa sampai nampak giginya kemudian ia bersabda:"Pergilah dan beri makanlah keluargamu (dengan korma tersebut). H.R.Jamaah ahli hadis. ${ }^{\mathbf{1 5}}$

Kasus serupa ini kata Turabi, tidak akan terjadi lagi dalam bentuk dan kejadian yang persis sama, namun suatu makna tertentu dapat disimpulkan dari peristiwa tersebut. Umpamanya ini adalah suatu perbuatan yang berakibat membatalkan puasa yang hal tersebut dapat dipergunakan untuk mengukur perbuatan yang lain yang melahirkan akibat membatalkan puasa juga, seperti makan dan minum dan lain-lain.

Mengenai metode ini, Turabi lebih lanjut berkomentar, bahwa metode qiyas ini bisa saja menjadi lebih luas atau lebih sempit, tergantung kepada sejauh mana kebebasannya dari persyaratan-persyaratan yang ditentukan untuk pelaksanakan qiyas tersebut dan efeknya terhadap perbaikan pembentukan hukum Islam. Qiyas maslahah mursalah adalah suatu qiyas yang lebih tinggi tingkatannya yang dipergunakan untuk meneliti dasar dari berbagai hukum, karena melalui qiyas tersebut kita dapat mengumpulkan sejumlah hukum mengenai kasus-kasus tertentu, kemudian merumuskan dari hukum-hukum tersebut suatu kemaslahatan yang bersifat umum. Melalui konsep maslahat seperti ini, kita dapat menemukan jalan 
untuk mengatur kehidupan sejalan dengan kehendak syara'.

2. Penggunaan istishāb yang luas (al-Istishāb al-Wāsi ${ }^{\text {) }}$

Ide tentang istishāb, jelas Turabi, adalah bahwa Islam diturunkan bukan untuk merekonstruksi kehidupan umat manusia berdasarkan kepada ketentuan-ketentuan yang sama sekali baru dan juga bukan untuk menghancurkan secara total ketentuan-ketentuan yang telah berlaku sebelumnya. Tetapi kedatangan Islam adalah untuk menjamin kesinambungan berlakunya praktik dan tradisi yang telah mapan yang sifatnya mencerminkan keadilan dan kebenaran, dan sekaligus memperbaiki serta memodifikasi praktek-praktek yang menyimpang dari keadilan. Rasulullah saw sendiri tidak menganggap bahwa segala norma yang berlaku sebelumnya dibatalkan, tidak berlaku, dan harus dihancurkan untuk membangun agama diatas prinsip yang sama sekali baru. Akan tetapi, prinsip yang digunakan adalah bahwa apa yang sudah diketahui oleh manusia dapat diterima, sementara agama diturunkan untuk memperbaiki urusan mereka yang menyimpang. ${ }^{16}$ Firman Allah swt:

Artinya:Jadilah engkau pema'af dan suruhlah orang mengerjakan yang ma'ruf, serta berpalinglah dari pada orang-orang yang bodoh.

Surat al-A'raf :199 ini yang isinya adalah suruhan untuk berbuat yang baik. Kata $m a$ 'rūf didalam ayat ini dapat dipahami sebagai mengandung dua makna, yaitu: dapat bermakna sebagai kebaikan dan praktik yang yang telah mapan yang diakui oleh syara', atau bisa juga bermakna sebagai pembatalan dan penolakan terhadap seluruh perbuatan salah dan tidak adil, yang dalam hal ini tentunya tidak ma'rūf. Hal ini kata Turabi adalah basis dari istishāb. Dari konsep istishāb tersebut, Hasan Turabi, merumuskan konsep kebolehan (al-Ibāhah) yang merupakan ketentuan umum dari syara' terhadap perbuatan atau tindakan yang dianggap bermanfaat dan tidak menimbulkan mudarat. Dengan kata lain, segala 
sesuatu itu boleh selama tidak ada indikasi yang melarangnya.

Hasan Turabi berkesimpulan bahwa prinsip istishāb bersama-sama dengan konsep qiyas yang konprehensif (qiyās $w \bar{a} s i^{\circ}$ ) dapat melahirkan usul fikih yang luas yang mampu melahirkan fikih yang lues dan dinamis yang pada gilirannya dapat menjawab segala permasalahan yang memenuhi kebutuhan kita yang senatiasa berkembang.

\section{Analisis}

Pembaharuan yang ditawarkan oleh Hassan Turabi sebagaimana yang telah penulis kemukakan ada dua yaitu alqiyās al-wāsi" dan al-istishāb al-wāsi'. Al-qiyās alwāsi (qiyas yang luas) merupakan pendapat yang diilhami oleh ulama-ulama usul fikih terdahulu, yang menggunakan qiyas sebagai suatu cara untuk menggali hukum yang tidak dijelaskan dalam Alquran maupun hadis.

Hasan Turabi dalam menggunakan qiyas yang lebih luas, nampaknya berbeda dengan rumusan yang digunakan oleh ulama usul fikih terdahulu. Sasaran qiyas yang dimaksud oleh Hasan turabi adalah masalah-masalah yang bersifat umum dan untuk kepentingan umum, bukan masalah nikah, maupun ibadah ritual lainnya. Kalau masalah seperti ini nampaknya Hasan Turabi masih berkiblat kepada rumusan ulama usul fikih terdahulu.

Ulama-ulama usul fikih sebelum Turabi didalam menggali hukum yang belum disebutkan oleh Alquran maupun hadis, mereka menggunakan qiyas. Qiyas yang dapat dipergunakan untuk menggali hukum mempunyai rukunrukun tertentu, yaitu; asal, cabang, 'illat dan hukum. ${ }^{17}$ Asal ialah masalah yang akan dijadikan pengqiyasan, umpamanya jika mengqiyaskan minuman yang memabukkan seperti wiski, maka yang menjadi asalnya ialah khamar dan wiski menjadi cabangnya, illatnya adalah unsur memabukkan. Hukum adalah hukum meminum khamar yaitu haram. Keharaman khamar karena adanya unsur iskār (memabukan) ${ }^{18}$ maka minum wiski juga hukumnya haram, 
karena mempunyai 'illat yang sama yaitu memabukkan. Dengan demikian antara masalah yang akan diqiyaskan dengan hukum asal mempunyai kesamaan 'illat, jika antara masalah yang akan diqiyaskan dengan hukum asal tidak ada kesamaan 'illat maka qiyas tidak dapat dilakukan. Inilah model qiyas yang telah dilakukan oleh ulama-ulama usul terdahulu semenjak Iman Syafi‘i.

Dalam masalah umum, Hasan Turabi menggunakan istilah yang sama, namun didalam aplikasi metodologinya berbeda dengan ulama usul. Qiyas yang digunakan oleh Hasan Turabi sebenarnya mengarah kepada maslahah almursalah, karena memang didalam prosedur penggunaan qiyas, Hasan Turabi berbeda dengan apa yang dilakukan oleh ulama usul. Ulama usul didalam prosedur pemakaian qiyas, adalah adanya kesamaan 'illat antara furu' dengan asl. Sedangkan Hasan Turabi didalam penggunaan qiyas, tidak ada menyinggung sedikitpun tentang 'illat, yang menjadi titik beratnya adalah adanya kemaslahatan bagi umat manusia.

Maslahah al-mursalah yang dmaksudkan dalam syari'at Islam yang disampaikan melalui wahyu yaitu Alquran maupun hadis bertujuan (maqāsid asy-syari'ah) untuk kemaslahatan umat manusia. Teori maqāsid sebenarnya sudah ada dikembangkan oleh ulama usul fikih sebelum HasanTuarabi, yaitu asy-Syātibī. (730-790 H) bahkan ulama-ulama sebelum asy-Syātibī juga ada yang menggunakan maslahah al-mursalah, seperti Imam Malik (93-179 H ).

Pembaharuan yang ditawarkan Al-Turabi yang ke dua ialah istishāb yang luas (al-Istishāb al-Wāsi ). Konsep $i s t i s h \bar{a} b$ ini sebenarnya telah digunakan jauh sebelum AlTurabi sudah digunakan oleh ulama-ulama klasik yaitu Malik, Hanafi, Syafi‘i, dan Ahmad bin Hanbal. Al-Turabi hanya menambahkan kata-kata $a l-w \bar{a} s i$ ' yang istilah tersebut tidak dipakai oleh ulama-ulama mutaqaddimin. Istishāb menurut pengertian yang dikemukakan oleh ulama-ulama usul ialah menganggap hukum sesuatu itu tetap seperti keadaanya semula karena tidak adanya dalil yang 
melarangnya atau belum adanya dalil yang merobahnya. ${ }^{19}$ Basis atau lapangan istishāb menurut Al-Turabi ialah tradisi atau adat istiadat yang berlaku di masyarakat yang telah berlaku turun temurun. Selama tradisi tersebut mempunyai nilai ma'ruf atau bermanfaat untuk umat manusia dan tidak adanya dalil yang melarangnya hukumnya adalah ibāhah (boleh). Akan tetapi lapangan istishāb menurut ulama usul tidak terbatas kepada mu'āmalah dan tradisi masyarakat yang sudah berlaku saja, akan tetapi merambah kepada hukumhukum ibadah, seperti seseorang yang sudah berwuduk kemudian ia ragu apakah wuduknya sudah atal atau belum, maka ia dihukumkan tetap masih berwuduk berdasarkan istishā $b^{20}{ }^{2}$ Kosep istishāb al-wāsi ' yang ditawarkan oleh AlTurabi yang berpendapat bahwa tradisi yang ma'ruf dapat terus berlaku selama belum adanya dalil yang melarangnya juga sudah dipergunakan oleh ulama-ulama usul sebelumya yang menyebutnya dengan 'uruf șahịh (tradisi yang baik). Adapun 'uruf fasid, yaitu 'uruf yang tidak sesuai dengan prinsip hukum Islam ataupun bertentangan dengan nilai-nilai keislaman tidak dapat dijadikan sebagai pertimbangan hukum.

\section{Kesimpulan}

Pembaharuan Usul Fikih yang ditawarkan Hasan alTurabi bukanlah merubah semua kerangka Usul Fikih yang telah dibuat oleh ulama-ulama usul, akan tetapi pembaharuan Usul Fikih Hasan al-Turabi hanya menawarkan dua masalah, yaitu:

1. Penggunaan al-qiyās al-wāsi' (qiyas yang luas dan konfrehensif) yang basisnya diambil dari mașālih almursalah. Pada prinsipnya syari'at Islam itu datang adalah untuk kemaslahatan(kebaikan) umat manusia dan bukan untuk menyengsarakan.

2. Penggunaan istishāb yang luas (al-Istishāb al-Wāsi ) yang basisnya adalah tradisi atau "uruf yang telah berlaku di masyarakat. Tradisi umat telah ada sebelum syari'at Islam itu datang. Islam diturunkan bukan untuk merekonstruksi 
kehidupan umat manusia berdasarkan kepada ketentuanketentuan yang sama sekali baru dan juga bukan untuk menghancurkan secara total ketentuan-ketentuan yang telah berlaku sebelumnya. Tetapi kedatangan Islam adalah untuk menjamin kesinambungan berlakunya praktik dan tradisi yang telah mapan yang sifatnya mencerminkan keadilan dan kebenaran, dan sekaligus memperbaiki serta memodifikasi praktek-praktek yang menyimpang dari keadilan.

Konsep pembaharuan Usul Fikih yang ditawarkan oleh Hasan al-Turabi ini sebenarnya sudah dirintis dan dimulai oleh ulama-ulama usul terdahulu. Al-Turabi mengambil istilah qiyās dan istishāb kemudian menambahinya dengan kata-kata al-wāsi' yang basisnya tidak jauh berbeda dengan pendapat ulama-ulama usul sebelumnya. Menurut penulis konsep Al-Turabi tersebut bukanlah hal yang baru tetapi masalah klasik yang sudah dibahas oleh ulama-ulama Usul Fikih sebelum Al-Turabi lahir.

\section{Daftar Pustaka}

Abd as-Salām al-Balājy, Tatawwur 'Ilm Usul al-Fiqh wa Tajaddudahu, T.t.p: Dār al-Wafā', 2007/1428

Abī Dāwud Sulaimān ibn al-Asy'aś as-Sijistāny al-Azdī, Sunan Abī Dāwud, Indonesia:Maktabah Dahlān,t.t., Jil IV

'Aly Hasb Allah, Ușul at-Tasyrī' al-Islāmy, Mesir: Dār alMa'ārif, 1959/1379

'Aly Syāmy an-Nasyār, Manāhij al-Bahśi 'Inda Mufakkry al-Islām, Iskandariyah: Dār al-Ma'ārif, t.t

Dewan Redaksi Ensiklopedia Islam, Ensiklopedia Islam, Jakarta:PT Ikrar Maudriaabadi, 2003

Hammādī al-Humaidī, asy-Syātibī wa Maqāsid asy-Syarī'ah, t.t.p :al-Jamāhir al- 'Uzamā, 1992

Hasan Al-Turabi, Fiqih Demokratis, Terj Abdul Haris dan Zainul Am, Bandung:Arasy ,2003 
Karen Amstrong, Berperang demi Tuhan Fundamentalisme Dalam Islam, Kristen, dan Yahudi, Bandung: PT Mizan Pustaka, 2004

Luois Mahluf, al-Munjid F̄̄ al-Lugah wa al-A 'lām, Beirut: Dār al-Masyriq,1986

Muhammad Abu Zahrah, Tārīkh al-Mazāhib al-Fiqhiyah, Kairo: Matba'ah al-Madany, t.t

Muhammad Abū Zahrah, Usūl al-Fiqh, Kairo:Dār al-Fikr al'Arabī,t.t

Muhammad bin 'Aly bin Muhammad asy-Syaukāny, Nail alAwtār, Mesir: Muștafā al-Bāb al-Halaby, t.t

Muhammad ibn 'Alī ibn Muhammad asy-Syawkān̄̄, Irsyāed al-Fuhūl, Beirut:Dār al-Kutub al-'Arabiyah,t.t.

Muhammad ibn Muhammad al-Husainī az-Zabīdī, Ittihāf asSādah al-Muttaqīn, Beirut:Dār al-Kutub al- 'Ilmiyah, t.t

Nasrun Haroen, Ushul Fiqh I, Jakarta: Logos Wacana Ilmu, t.t

Nawir Yuslem, Gerakan Hasan Turabi Tentang Tajdìd Usūl Al-Fikih,dalam Analytica Islamica, t.t

Sya'bān Muhammad 'Ismā'īl, at-Tajdīd F̄̄ Usūl al-Fiqh, Mekah:Maktabah al-Makkiyah, t.t 